\title{
Ni⿺辶卬 \\ First report of Rhizoctonia solani anastomosis group 5 (AG5) in wheat in the UK
}

\author{
J.W. Woodhall*, L. Laurenson and J.C. Peters \\ The Food and Environment Research Agency, Sand Hutton, York, YO41 1LZ \\ *E-mail: james.woodhall@fera.gsi.gov.uk
}

Received: 07 Jun 2012. Published: 15 Sep 2012. Keywords: Triticum aestivum, Thanatephorus cucumeris, real-time PCR

A sample of wheat (cv. Grafton) was taken from a field in Shropshire in May 2010. Brown lesions were present on two stems 5-15 mm from the stem base and also browning of the roots was observed. From the affected stems, pure Rhizoctonia cultures were obtained as previously described (Woodhall et al., 2007) and these were identified as Rhizoctonia solani AG5 by the AG5 specific real-time PCR assay (Budge et al., 2009). Isolate identity was confirmed by sequencing of the rDNA ITS region with primers ITS1 and ITS4. Sequencing was undertaken using an Applied Biosystems 3130xl Genetic Analyzer. The resulting sequence (GenBank Accession No. HE667746) was compared to other sequences and was $99 \%$ identical to other AG5 sequences in GenBank. Four 18-mm plugs of the isolate cultured on potato dextrose agar and were used to inoculate John Innes No. 3 compost into which wheat (cv. Einstein) was planted. After three weeks in a controlled environment room at $18^{\circ} \mathrm{C}$ and $50 \%$ relative humidity, brown lesions were observed on the stems. Re-isolation of the fungus from the wheat plant and confirmation of the resulting isolate as AG5 by real-time PCR satisfied Koch's postulates.

Soil samples $(250 \mathrm{~g})$ had been taken from the field in the previous year. DNA was extracted from soil using the method of Woodhall et al. (in press) and AG5 DNA was quantified using real-time PCR. In May 2009, no AG5 DNA was detected. At this time, a potato crop was being grown in the field. In October 2009, after wheat had been planted the month before, $456 \mathrm{pg}$ DNA/g soil was detected. In May 2010, this had increased to 2084 pg DNA/g soil, indicating that levels of $R$. solani AG5 in the soil had increased with the presence of wheat and therefore suggesting some interaction between wheat and the fungus. Interestingly, in September $2011, R$. solani AG5 was isolated from a decaying barley plant found in an adjacent field.

To the authors' knowledge, this is the first report of AG5 infecting wheat in the UK. AG5 has been reported on wheat previously. Demirci (1998) reported AG5 on wheat in Turkey and reported that it was pathogenic to wheat and barley. Gudmestead et al. (1989) reported that $56 \%$ of $R$. solani isolates from wheat in potato producing areas of North Dakota were AG5. $R$. solani is an important pathogen of many crops worldwide, including cereals and potatoes. AG5 has been reported on potatoes in the UK previously (Woodhall et al., 2007) and also on couch grass (Woodhall et al., 2004). Further work is required to characterise the importance of $R$. solani AG5 in wheat. In this study, soil levels of AG5 appeared to increase when wheat was present. Therefore, planting potatoes after wheat may result in an increased risk of potato disease caused by R. solani AG5.

\section{Acknowledgements}

The authors acknowledge support from the AHDB (Potato Council), UK.

\section{References}

Budge GE, Shaw MW, Colyer A, Pietravalle S, Boonham N, 2009.

Molecular tools to investigate Rhizoctonia solani distribution in soil. Plant Pathology 58, 1071-1080. [http://dx.doi.org/10.1111/j.1365-3059.2009.02139.x]

Demirci E, 1998. Rhizoctonia species and anastomosis groups isolated from barley and wheat in Erzurum, Turkey. Plant Pathology 47, 10-15. [http://dx.doi.org/10.1046/j.1365-3059.1998.00214.x]

Gudmestad NC, Stack RW, Salas B, 1989. Colonization of potato by Rhizoctonia solani as affected by crop rotation. In: Vos J, van Loon CD, eds. Effects of crop rotation on potato production in the temperate zones. Dordrecht, Netherlands: Kluwer, 247-252.

Woodhall JW, Lees AK, 2004. First report of Rhizoctonia solani anastomosis group 5 (AG5) on couch grass in Britain. Plant Pathology 53, 538. [http://dx.doi.org/10.1111/j.1365-3059.2004.01041.x]

WoodhallJW, LeesAK, Edwards SG, Jenkinson P, 2007. Characterization of Rhizoctonia solani from potato in Great Britain. Plant Pathology $\mathbf{5 6}$, 286-295. [http://dx.doi.org/10.1111/j.1365-3059.2006.01545.x]

Woodhall JW, Webb KM, Giltrap PM, Adams IP, Peters JC, Budge GE, Boonham N, 2012 (early view). A new large scale soil DNA extraction procedure and real-time PCR assay for the detection of Sclerotium cepivorum in soil. European Journal of Plant Pathology.

[http://dx.doi.org/10.1007/s10658-012-0025-2]

To cite this report: Woodhall JW, Laurenson L, Peters JC, 2012. First report of Rhizoctonia solani anastomosis group 5 (AG5) in wheat in the UK. New Disease Reports 26, 9. [http://dx.doi.org/10.5197/j.2044-0588.2012.026.009] 